\title{
Nitrous oxide emissions from maize-wheat field during 4 successive years in the North China Plain
}

\author{
Y. Zhang, Y. Mu, Y. Zhou, J. Liu, and C. Zhang \\ Research Center for Eco-Environmental Sciences, Chinese Academy of Sciences, Beijing 100085, China \\ Correspondence to: Y. Mu (yjmu@ rcees.ac.cn)
}

Received: 17 October 2013 - Published in Biogeosciences Discuss.: 26 November 2013

Revised: 17 February 2014 - Accepted: 18 February 2014 - Published: 1 April 2014

\begin{abstract}
Agricultural soil with fertilization is a main anthropogenic source for atmospheric nitrous oxide $\left(\mathrm{N}_{2} \mathrm{O}\right)$. $\mathrm{N}_{2} \mathrm{O}$ fluxes from a maize-wheat rotation field in the North China Plain (NCP) were investigated for 4 successive years using the static chamber method. The annual $\mathrm{N}_{2} \mathrm{O}$ fluxes from the control (without fertilization) and fertilization plots were $1.5 \pm 0.2$ and $9.4 \pm 1.7 \mathrm{~kg} \mathrm{Nha}^{-1} \mathrm{yr}^{-1}$ in 2008 $2009,2.0 \pm 0.01$ and $4.0 \pm 0.03 \mathrm{~kg} \mathrm{Nha}^{-1} \mathrm{yr}^{-1}$ in 2009 $2010, \quad 1.3 \pm 0.02$ and $5.0 \pm 0.3 \mathrm{~kg} \mathrm{Nha}^{-1} \mathrm{yr}^{-1}$ in 2010 2011 , and $2.7 \pm 0.6$ and $12.5 \pm 0.1 \mathrm{~kg} \mathrm{Nha}^{-1} \mathrm{yr}^{-1}$ in $2011-$ 2012, respectively. Annual direct emission factors $\left(\mathrm{EF}_{d}\right.$ 's) in the corresponding years were $2.4 \pm 0.5 \%, 0.60 \pm 0.01 \%$, $1.1 \pm 0.09 \%$ and $2.9 \pm 0.2 \%$, respectively. Significant linear correlation between fertilized-induced $\mathrm{N}_{2} \mathrm{O}$ emissions $(Y$, $\mathrm{kg} \mathrm{Nha}^{-1}$ ) during the periods of 10 days after fertilization and rainfall intensities from 4 days before to 10 days after fertilization $(X, \mathrm{~mm})$ in the 4 years was found as $Y=$ $0.048 X-1.1\left(N=4, R^{2}=0.99, P<0.05\right)$. Therefore, the remarkable interannual variations of $\mathrm{N}_{2} \mathrm{O}$ emissions and the $\mathrm{EF}_{d}$ 's were mainly ascribed to the rainfall.
\end{abstract}

\section{Introduction}

Emissions of nitrous oxide $\left(\mathrm{N}_{2} \mathrm{O}\right)$ to the atmosphere have attracted much attention because of its significance for greenhouse effect and depletion of stratospheric ozone (Crutzen, 1970; Bolle et al., 1986). Agricultural soil has been recognized as a main source of anthropogenic $\mathrm{N}_{2} \mathrm{O}$ emissions to the atmosphere (Khalil et al., 2006) and contributes about $65 \%$ of total anthropogenic $\mathrm{N}_{2} \mathrm{O}$ emission (Smith, 1997). It is well known that $\mathrm{N}_{2} \mathrm{O}$ is a by-product in microbial nitrification and an intermediate in denitrification process (Fire- stone and Davidson, 1989). $\mathrm{N}_{2} \mathrm{O}$ emissions from soils are strongly affected by many factors, e.g., soil temperature and moisture, soil aeration status and carbon availability (Smith et al., 2003; Ruser et al., 2006), crop type and residue management (Raich and Tufekcioglu, 2000; Huang et al., 2004; Chen et al., 2008), and the management of nitrogen (N) fertilizer (Hao et al., 2001; Bouwman et al., 2002). Among the various influence factors, fertilization, soil temperature and moisture play important roles on $\mathrm{N}_{2} \mathrm{O}$ emission. Fertilization directly provides substrate for soil nitrifying and denitrifying microbes, and soil temperature and moisture have major impacts on soil microorganisms (Smith et al., 2003). The microbial process generally increases exponentially with soil temperature when other factors are not limiting (Meixner and Yang, 2006). Soil water content plays important roles not only on the substrate supply for the microorganisms (Meixner and Yang, 2006) but also on gas diffusivity (Smith et al., 2003). Increasing soil moisture is conducive to produce anaerobic condition and thus promotes $\mathrm{N}_{2} \mathrm{O}$ formation via denitrification (Dobbie and Smith, 2001). Large temporal-spatial variation of $\mathrm{N}_{2} \mathrm{O}$ emission from agricultural fields could be expected due to the changes of the various influence factors. For example, there are great uncertainties in $\mathrm{N}_{2} \mathrm{O}$ emission from agricultural fields with the reported direct emission factors $\left(\mathrm{EF}_{d}\right.$ 's) of 0-7 \% for mineral soils (Bouwman, 1996). Therefore, it is necessary to conduct long-term $\mathrm{N}_{2} \mathrm{O}$ flux measurements different agricultural field to reduce the uncertainties of $\mathrm{N}_{2} \mathrm{O}$ estimation (Barton et al., 2008; Scheer et al., 2008).

North China Plain (NCP) is one of the greatest grain production areas in China. Maize and wheat, the main grain crops in this region, provide $39 \%$ and $48 \%$ of the total maize and wheat yields in China, respectively (Liu and Mu, 1993). 
Table 1. The amount, date and type of nitrogen fertilizer application in the experiment field.

\begin{tabular}{llllllll}
\hline \multirow{2}{*}{ Year } & \multicolumn{2}{c}{ Fertilization timing } & \multicolumn{2}{c}{ Fertilizer type } & \multicolumn{2}{l}{ Fertilizer rate $\left(\mathrm{kg} \mathrm{Nha}^{-1}\right)$} \\
\cline { 2 - 8 } & $\mathrm{B}$ & $\mathrm{S}$ & $\mathrm{B}$ & $\mathrm{S}$ & $\mathrm{B}$ & $\mathrm{S}$ & $\mathrm{T}$ \\
\hline Maize & & & & & & & \\
2008 & 25 June 2008 & 16 August 2008 & NPK & NK & 89 & 83 & 172 \\
2009 & 29 June 2009 & 1 August 2009 & NPK & Urea & 99 & 69 & 168 \\
2010 & 30 June 2010 & 6 August 2010 & NPK & NK & 107 & 69 & 176 \\
2011 & 30 June 2011 & 8 August 2011 & NPK & NK & 107 & 69 & 176 \\
Wheat & & & & & & & \\
$2008-2009$ & 18 October 2008 & 4 April 2009 & NPK & Urea & 75 & 88 & 163 \\
$2009-2010$ & 13October 2009 & 20 April 2010 & NPK & NK & 60 & 105 & 165 \\
$2010-2011$ & 17 October 2010 & 14 April 2011 & NPK & NS & 60 & 105 & 165 \\
$2011-2012$ & 19 October 2011 & 18 April 2012 & NPK & Urea & 60 & 105 & 165 \\
\hline
\end{tabular}

B: basal fertilizer, S: supplemental fertilizer, T: total fertilization rate, NPK, NK, NS: compound fertilizers contained nitrogen $(\mathrm{N})$, phosphorus $(\mathrm{P})$, potassium $(\mathrm{K})$ and sulfur $(\mathrm{S})$.

The NCP has a cultivated land area of 17.95 million ha, which accounts for $18.6 \%$ of the total agricultural area in China (Liu et al., 2001), and consumes about $30 \%$ of the total national N-fertilizer (Zhang et al., 2004). As N-fertilizer is the necessary substrate for soil nitrification and denitrification, the huge amounts of $\mathrm{N}$-fertilizer applications in this region can greatly stimulate $\mathrm{N}_{2} \mathrm{O}$ emission. Therefore, $\mathrm{N}_{2} \mathrm{O}$ emissions from the agricultural fields in the NCP have been investigated intensively (Zeng et al., 1995; Dong et al., 2000; Meng et al., 2005; Ding et al., 2007, 2013; Sun et al., 2008; Wang et al., 2008, 2009; Li et al., 2010; Cui et al., 2012; Cai et al., 2013; Hu et al., 2013; Shi et al., 2013; Yan et al., 2013). However, among those reports on $\mathrm{N}_{2} \mathrm{O}$ emissions from the fields, many studies were conducted for 1 year, and only the studies of Cai et al. (2013), Hu et al. (2013) and Yan et al. (2013) implemented the $\mathrm{N}_{2} \mathrm{O}$ measurement for more than 1 year. According to these treatment-site-year data, large differences of $\mathrm{N}_{2} \mathrm{O}$ emissions (ranging from 0.77 to $6.0 \mathrm{~kg} \mathrm{~N} \mathrm{ha}^{-1} \mathrm{yr}^{-1}$ ) and $\mathrm{EF}_{d}$ 's (in the range of $0.10-1.0 \%$ ) from the agricultural fields in the NCP were obtained.

In this study, the $\mathrm{N}_{2} \mathrm{O}$ flux from a maize-wheat rotation system in the NCP was investigated from 2008 to 2012. The objectives of this study were (1) to understand the interannual variation of $\mathrm{N}_{2} \mathrm{O}$ emission and (2) to determine the key influence factors on $\mathrm{N}_{2} \mathrm{O}$ emission.

\section{Materials and methods}

\subsection{Field experiment}

This study was conducted in a summer maize (Zea mays L.) and winter wheat (Triticum aestivum L.) rotation system in Wangdu County $\left(38^{\circ} 71^{\prime} \mathrm{N}, 115^{\circ} 15^{\prime} \mathrm{E}\right)$, Baoding City, Hebei Province, China. Detailed information about the experiment field has been mentioned in our previous papers (Zhang et al., 2011, 2012).
The field experiment was conducted with two different treatments: control (CK, without fertilization) and chemical $\mathrm{N}$-fertilizer (NP). Only with the exception of fertilization, the two plots were identically managed. Each plot $(6.5 \times$ $3.5 \mathrm{~m}^{2}$ ) was separated by a $1.2 \mathrm{~m}$ broad zone to prevent nutrient transfer between treatments. Maize and wheat were planted in June and October each year, respectively, and the field was tilled before wheat sowing. Field managements including fertilization, irrigation, herbicide and pesticide applications strictly followed the cultivating manner of local farmers. Detailed information about fertilizer management is listed in Table 1.

\section{$2.2 \quad \mathrm{~N}_{2} \mathrm{O}$ fluxes measurement}

$\mathrm{N}_{2} \mathrm{O}$ fluxes were investigated in the summer maize-winter wheat field from June in 2008 to October in 2012. Static chambers $\left(60 \times 60 \times 90 \mathrm{~cm}^{3}\right)$ were adopted to monitor $\mathrm{N}_{2} \mathrm{O}$ fluxes. Three stainless steel pedestals were inserted $10 \mathrm{~cm}$ into the soils of each plot during the whole growing season. The densities of sowing for maize and wheat in the pedestals were the same as the densities in the surrounding area. Four maize seeds (in June) and about 280 wheat seeds (in October) were kept in each pedestal, respectively. The top part of the maize plant above the chamber was cut off when its height exceeded $80 \mathrm{~cm}$ (after $\sim 40$ days growing). $\mathrm{N}_{2} \mathrm{O}$ fluxes were measured every day within duration of more than 10 days after fertilization (except the period of basal fertilizer application in 2008 maize season), then continuous sampling for 5-11 days monthly (2008-2010 maize-wheat rotations) or once to twice weekly (2010-2012 maize-wheat rotations) during other periods of crops' growing seasons excluding the winters (from December to February) in 2008-2010 maizewheat rotations. On each sampling day, $\mathrm{N}_{2} \mathrm{O}$ flux was measured at around 9.30 a.m. (Beijing time). Four gas samples were taken from the headspace by a sampling minipump (NMP $830 \mathrm{KNDC}$, Germany) to aluminum combined 
polyester gas sampling bags ( $200 \mathrm{~mL}$, Delin, Dalian, China) at $10 \mathrm{~min}$ intervals after the chambers were deployed. The first sample was taken after 2 min of covering chambers.

$\mathrm{N}_{2} \mathrm{O}$ concentrations were determined using a gas chromatograph (GC, Model SP3410, Beijing Analytical Instrument Factory) equipped with ${ }^{63} \mathrm{~N}$ electron capture detector (ECD). An improved GC-ECD method was applied to measure $\mathrm{N}_{2} \mathrm{O}$ concentration in this study (Zhang et al., 2013). High purity of $\mathrm{N}_{2}(99.999 \%)$ was used as carrier gas, and a makeup gas (979 ppmv $\mathrm{CO}_{2}$ in $\mathrm{N}_{2}$ ) was introduced into the downstream of the analytical column. The variation coefficient of our method for analyzing $\mathrm{N}_{2} \mathrm{O}$ was less than $0.31 \%$. The negligible influence of $\mathrm{CO}_{2}$ on $\mathrm{N}_{2} \mathrm{O}$ measurement and the good linear correlation between the GC-ECD responses and $\mathrm{N}_{2} \mathrm{O}$ concentrations were found by our improved GC-ECD method (Zhang et al., 2013). The $\mathrm{N}_{2} \mathrm{O}$ flux $\left(F, \mathrm{ng} \mathrm{N} \mathrm{m}^{-2} \mathrm{~s}^{-1}\right)$ was calculated by the following equation:

$F=H \times \frac{\Delta C}{\Delta t} \times \frac{P}{R T} \times M_{\mathrm{N}} \times 10^{3}$,

where $H$ is the chamber headspace height (m), $C / t$ is the slope $\left(\mathrm{ppbv} \mathrm{s}^{-1}\right.$ ) of the linear regression of $\mathrm{N}_{2} \mathrm{O}$ concentration in the chamber with time $\left(R^{2}>0.85\right), P$ is the atmospheric pressure (atm) measured in the field, $R$ is the gas constant $\left(0.082 \mathrm{~atm} \mathrm{~L} \mathrm{~K}^{-1} \mathrm{~mol}^{-1}\right), T$ is the ambient air temperature $(\mathrm{K})$ and $M_{\mathrm{N}}$ is the molecular weight of $\mathrm{N}_{2} \mathrm{O}-\mathrm{N}$ $\left(28 \mathrm{~g} \mathrm{~mol}^{-1}\right)$.

\subsection{Measurement of soil characteristics}

Four soil samples in each plot were collected from $0-10 \mathrm{~cm}$ soil layer using a stainless steel soil sampler and were mixed carefully for the analysis of soil mineral $\mathrm{N}\left(\mathrm{NH}_{4}^{+}\right.$$\mathrm{N}$ and $\left.\mathrm{NO}_{3}^{-}-\mathrm{N}\right)$ concentrations by a colorimetric continuous flow analyzer (SANT++, Skalar Company, the Netherlands). The samples from 0 to $5 \mathrm{~cm}$ topsoil were determined gravimetrically by oven drying at $105^{\circ} \mathrm{C}$ for $12 \mathrm{~h}$ and expressed as water-filled pore space (WFPS). Total porosity and WFPS were calculated based on water content, soil bulk density and a particle density of $2.65 \mathrm{~g} \mathrm{~cm}^{-3}$. Soil temperature was recorded on each gas-sampling day at a depth of $10 \mathrm{~cm}$, while only the soil temperatures in the CK treatment were recorded in 2008. The data of precipitation were from http://www.wunderground.com.

\subsection{Date calculation and statistical analysis}

The statistical analysis was conducted by Origin 8.0 (Origin Lab Corporation, USA) and SPSS 13.0 software (SPSS Inc., Chicago, USA). Prior to analysis, data of $\mathrm{N}_{2} \mathrm{O}$ fluxes and driving factors were log-transformed as needed to normalize the distributions. Paired-samples $T$ test was adopted to analyze the difference between CK and NP treatments during the periods of 4 years excluding the 10-day durations following each fertilization event. Stepwise linear regression analysis was performed to examine the relationships between $\mathrm{N}_{2} \mathrm{O}$ fluxes and important driving factors, and only the regression equations that have statistical significance are listed in this study. Significance of all tests was accepted at $P<0.05$.

The $\mathrm{N}_{2} \mathrm{O}$ fluxes presented in the figures are the arithmetic means of the replications in each treatment. The cumulative $\mathrm{N}_{2} \mathrm{O}$ emission from each treatment was estimated by linear interpolation between the sampling days. The $\mathrm{EF}_{d}$ 's during the investigation periods were calculated as the difference between the cumulative $\mathrm{N}_{2} \mathrm{O}-\mathrm{N}$ emission from the fertilized and control plots divided by the amount of $\mathrm{N}$ fertilizer applied. The standard error of the direct emission factor was estimated using the standard errors for the cumulative emissions from the fertilized and the unfertilized plots (Cui et al., 2012).

\section{Results}

\subsection{Environmental variables}

The variations of soil moisture were mainly regulated by precipitation and irrigation. Generally, soil moisture would increase quickly after irrigation (WFPS $>60 \%$ ), and it could reach $80 \%$ or above when precipitation happened just after irrigation (Fig. 1a-d). The annual precipitation was 352, 356, 306 and $383 \mathrm{~mm}$ during the 2008-2009, 2009-2010, 2010 2011 and 2011-2012 maize-wheat rotations, respectively, and the precipitation in the maize season accounted for 75 , 62,64 and $79 \%$ of the total amount in each year, respectively. The mean soil moisture (WFPS) values in the CK and NP plots were 57 and $65 \%, 48$ and $64 \%, 55$ and $55 \%, 68$ and $69 \%$ in the 2008-2009, 2009-2010, 2010-2011 and 20112012 maize-wheat rotation years, respectively. The average soil temperatures of the $\mathrm{CK}$ and NP plots were 26.7, 22.5, 26.4 and $25.5^{\circ} \mathrm{C}$ in the $2008,2009,2010$ and 2011 maize growing seasons, and were $12.9,11.0,11.0$ and $9.3^{\circ} \mathrm{C}$ in the corresponding wheat seasons, respectively.

\section{2 $\quad \mathrm{N}_{2} \mathrm{O}$ fluxes and key influence factors}

The temporal variations of $\mathrm{N}_{2} \mathrm{O}$ fluxes from the $\mathrm{CK}$ and $\mathrm{NP}$ plots during the 4 years are illustrated in Fig. 2. $\mathrm{N}_{2} \mathrm{O}$ emissions from the CK treatment were in the range of $-37-70 \mathrm{ng} \mathrm{N} \mathrm{m}^{-2} \mathrm{~s}^{-1}$, and obvious emission pulses occasionally occur after irrigation and rainfall events. As for the NP treatment, the relatively high $\mathrm{N}_{2} \mathrm{O}$ emissions (75$624 \mathrm{ng} \mathrm{N} \mathrm{m}^{-2} \mathrm{~s}^{-1}$ ) usually occurred after fertilization, and the $\mathrm{N}_{2} \mathrm{O}$ emission was from -19 to $33 \mathrm{ng} \mathrm{N} \mathrm{m}^{-2} \mathrm{~s}^{-1}$ during the periods of pre- and post-fertilizer application. Negative $\mathrm{N}_{2} \mathrm{O}$ fluxes (uptake, i.e., fluxes from the atmosphere to the soil) were occasionally observed in the $\mathrm{CK}$ and NP plots in this study, which accounted for $4-10 \%$ of total investigation data in each maize-wheat rotation. The $\mathrm{N}_{2} \mathrm{O}$ concentrations were usually measured within 10 days, and the variation coefficient of $\mathrm{N}_{2} \mathrm{O}$ concentrations in gas bags during 

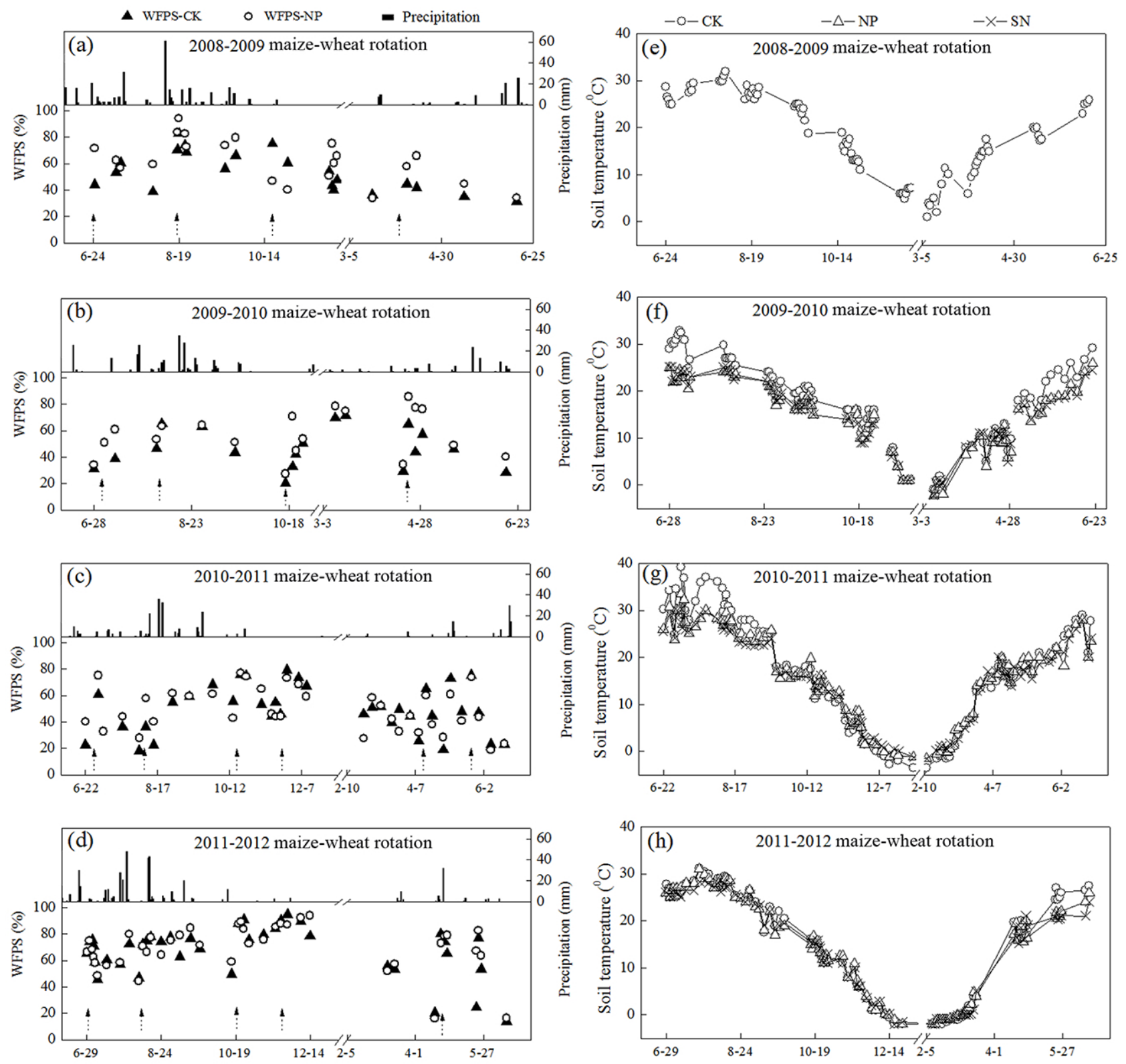

Fig. 1. Precipitation, soil WFPS $(\mathbf{a}, \mathbf{b}, \mathbf{c}, \mathbf{d})$ and soil temperatures $(\mathbf{e}, \mathbf{f}, \mathbf{g}, \mathbf{h})$ in the CK and NP treatments during 2008-2012 maize-wheat rotations. Dashed arrows show irrigation events.

storage and transportation was less than $1 \%$. Considering the flux detection limit was $1.6 \mathrm{ng} \mathrm{N} \mathrm{m}^{-2} \mathrm{~s}^{-1}$ in this study, the negative fluxes close to the flux detection limit could be ascribed to the instable instrument signal, while the large uptakes $\left(-37 \mathrm{ng} \mathrm{N} \mathrm{m}^{-2} \mathrm{~s}^{-1}\right.$ in the $\mathrm{CK}$ and $-19 \mathrm{ng} \mathrm{N} \mathrm{m}^{-2} \mathrm{~s}^{-1}$ in the NP treatments) were due to the denitrification and nitrifier denitrification (Chapuis-Lardy et al., 2007). Many researches also reported evident negative $\mathrm{N}_{2} \mathrm{O}$ fluxes from agriculture fields (e.g., Yamulki et al., 1995; Mahmood et al., 1998; Cui et al., 2012; Yan et al., 2013).
As shown in Fig. 2, $\mathrm{N}_{2} \mathrm{O}$ emission peaks induced by fertilization usually occurred at the first through fifth day after fertilization following irrigation in each growing season, while they delayed 1-2 days when rainfall events occurred just after fertilizations, e.g., on 21 August 2008, 5 July and 5 August 2009 (Fig. 2a and b). Generally, the $\mathrm{N}_{2} \mathrm{O}$ peaks only lasted for 1 day and then decreased quickly, while the high $\mathrm{N}_{2} \mathrm{O}$ emissions (about $550 \mathrm{ng} \mathrm{N} \mathrm{m}^{-2} \mathrm{~s}^{-1}$ ) sustained 3 days after basal fertilization following showers (from 1 July to 2 July) in 2011 maize season (Fig. 2d). Therefore, precipitation coincided with the fertilization would probably promote 
Table 2. Regression analysis between $\mathrm{N}_{2} \mathrm{O}$ flux $\left(\mathrm{ng} \mathrm{N} \mathrm{m}^{-2} \mathrm{~s}^{-1}\right)$ and its regulating factors in the maize-wheat field.

\begin{tabular}{|c|c|c|c|c|}
\hline Treatment & Factors & $B$ & $R^{2}$ & Equation \\
\hline \multicolumn{5}{|c|}{ 2009-2010 maize-wheat rotation } \\
\hline \multirow[t]{2}{*}{ CK } & WFPS & 0.021 & 0.31 & $\operatorname{lgN} \mathrm{N}_{2} \mathrm{O}=0.021 \mathrm{WFPS}+0.052 \mathrm{ST}-0.94$ \\
\hline & ST & 0.052 & 0.52 & $(N=17, R=0.82, P<0.001)$ \\
\hline \multirow[t]{2}{*}{ NP } & WFPS & 0.012 & 0.18 & $\operatorname{lgN}_{2} \mathrm{O}=0.012$ WFPS $+0.33 \operatorname{lgNH}{ }_{4}^{+}-\mathrm{N}+0.49$ \\
\hline & $\operatorname{lgNH} H_{4}^{+}-\mathrm{N}$ & $\begin{array}{l}0.33 \\
201\end{array}$ & $\begin{array}{l}0.29 \\
-2011\end{array}$ & $\begin{array}{l}(N=20, R=0.684, P<0.01) \\
\text { aize-wheat rotation }\end{array}$ \\
\hline \multirow[t]{5}{*}{ NP } & WFPS & 0.018 & 0.23 & $\lg \mathrm{N}_{2} \mathrm{O}=0.018 \mathrm{WFPS}+0.041 \mathrm{ST}+$ \\
\hline & ST & 0.041 & 0.27 & $0.011 \mathrm{NO}_{3}^{-}-\mathrm{N}+0.60 \operatorname{lgNH}_{4}^{+}-\mathrm{N}-1.4$ \\
\hline & $\mathrm{NO}_{3}^{-}-\mathrm{N}$ & 0.011 & 0.067 & $(N=30, R=0.61, P<0.05)$ \\
\hline & $\operatorname{lgNH}_{4}^{+}-\mathrm{N}$ & 0.60 & 0.12 & \\
\hline & \multicolumn{4}{|c|}{ 2011-2012 maize-wheat rotation } \\
\hline NP & $\operatorname{lgNH}{ }_{4}^{+}-\mathrm{N}$ & 0.77 & 0.20 & $\begin{array}{l}\operatorname{lgN}_{2} \mathrm{O}=0.77 \operatorname{lgNH}_{4}^{+}-\mathrm{N}+0.87 \\
(N=28, R=0.48, P<0.05)\end{array}$ \\
\hline
\end{tabular}

B: regression coefficient, $\mathrm{ST}$ : soil temperature $\left({ }^{\circ} \mathrm{C}\right)$ at a depth of $10 \mathrm{~cm}$; unit of mineral $\mathrm{N}\left(\mathrm{NO}_{3}^{-}-\mathrm{N}\right.$ and $\left.\mathrm{NH}_{4}^{+}-\mathrm{N}\right): \mathrm{mg} \mathrm{kg}^{-1}$ dry soil.

$\mathrm{N}_{2} \mathrm{O}$ emission because of the substrate supplement and development of anaerobic soil condition.

The $\mathrm{N}_{2} \mathrm{O}$ emission peaks from the NP treatment were 294, 142, 503 and $558 \mathrm{ng} \mathrm{N} \mathrm{m}^{-2} \mathrm{~s}^{-1}$ in 2008, 2009, 2010 and 2011 maize seasons, respectively, and were 75, 100, 147 and $624 \mathrm{ng} \mathrm{N} \mathrm{m}^{-2} \mathrm{~s}^{-1}$ in 2008-2009, 2009-2010, 20102011 and 2011-2012 wheat seasons, respectively. The $\mathrm{N}_{2} \mathrm{O}$ emission peaks after basal or supplemental fertilizer application were usually higher during the maize seasons than during the wheat seasons, which might be due to the relatively low soil temperature in the wheat seasons (Fig. 1e-h). However, the maximal peak of $\mathrm{N}_{2} \mathrm{O}$ emission $\left(624 \mathrm{ng} \mathrm{N} \mathrm{m}^{-2} \mathrm{~s}^{-1}\right)$ from the NP treatment among the 4 investigated years appeared in the 2012 wheat season after the supplemental fertilization, which was 4-8 times higher than those in other wheat seasons. During the period of $\mathrm{N}_{2} \mathrm{O}$ peak emission from the NP treatment in the 2012 wheat season, the soil WFPS $(78 \%)$ was evidently higher than those in 2009 (66\%) and $2011(60 \%)$ wheat seasons (Fig. 1a, c and d). Although higher WFPS (82\%) was observed after the supplemental fertilizer application in the wheat season of 2010 , the obvious low soil temperature $\left(10^{\circ} \mathrm{C}\right)$ compared with that $\left(15.5^{\circ} \mathrm{C}\right)$ in 2012 greatly restricted the activities of soil microorganisms (Meixner and Yang, 2006). Therefore, the higher $\mathrm{N}_{2} \mathrm{O}$ emission in the wheat season of 2012 was due to the synergistic effect of appropriate soil temperature $\left(15.5^{\circ} \mathrm{C}\right)$ and WFPS (78\%), which could build the soil microenvironment in favor of denitrification, and thus promote the $\mathrm{N}_{2} \mathrm{O}$ emission (Dobbie and Smith, 2001).

To elucidate the influence of various driving factors on $\mathrm{N}_{2} \mathrm{O}$ emission, the regression analysis between $\mathrm{N}_{2} \mathrm{O}$ fluxes and important driving factors was conducted as shown in Table 2. Evidently, $\mathrm{N}_{2} \mathrm{O}$ emission positively correlated with soil mineral N, temperature and WFPS. Soil temperature and
WFPS could explain $27-52 \%$ and $18-31 \%$ of the $\mathrm{N}_{2} \mathrm{O}$ emission, respectively. However, not all factors displayed significant influences on the $\mathrm{N}_{2} \mathrm{O}$ emission in each year and treatment, and a similar conclusion has been drawn by other studies (Wang et al., 2005; Rowlings et al., 2012).

\subsection{Cumulative $\mathrm{N}_{2} \mathrm{O}$ emissions and emission factors}

The cumulative $\mathrm{N}_{2} \mathrm{O}$ emissions and $\mathrm{EF}_{d}$ 's are listed in Table 3. The lowest emissions always occurred in the CK treatment, with the 4-year mean fluxes of $0.6 \mathrm{~kg} \mathrm{~N} \mathrm{ha}^{-1}$ in the maize season, $1.3 \mathrm{~kg} \mathrm{Nha}^{-1}$ in the wheat season and $1.9 \mathrm{~kg} \mathrm{Nha}^{-1}$ in the whole year. The annual cumulative $\mathrm{N}_{2} \mathrm{O}$ emissions from the NP treatment in the 2009-2010 and 2010-2011 were close, and extremely high $\mathrm{N}_{2} \mathrm{O}$ emissions were observed in the 2008-2009 and 2011-2012 maizewheat rotations. Mean cumulative $\mathrm{N}_{2} \mathrm{O}$ emissions from the NP treatment in the maize, wheat growing seasons and the whole year were $4.4,3.3$ and $7.7 \mathrm{~kg} \mathrm{Nha}^{-1}$, with the variation coefficients of 46,90 and $51 \%$, respectively.

The annual $\mathrm{EF}_{d}$ 's were $2.4 \pm 0.5 \%, 0.6 \pm 0.01 \%$, $1.1 \pm 0.09 \%$ and $2.9 \pm 0.2 \%$ in 2008-2012 maize-wheat rotations, respectively (Table 3). The mean 4-year $\mathrm{EF}_{d}$ in the maize season $(2.2 \%)$ was 1.8 times higher than that in the wheat season.

\section{Discussion}

\subsection{Interannual variation of $\mathrm{N}_{2} \mathrm{O}$ emission}

The above results well revealed evident interannual variation of $\mathrm{N}_{2} \mathrm{O}$ emissions from the agricultural field during the 4 successive years. Considering the nearly identical $\mathrm{N}$-fertilization rates and similar irrigation operations in each year, the interannual variation of $\mathrm{N}_{2} \mathrm{O}$ emissions was mainly ascribed to 
Table 3. Cumulative nitrous oxide $\left(\mathrm{N}_{2} \mathrm{O}\right)$ fluxes (mean $\left.\pm \mathrm{SE}\right)$ and direct emission factors $\left(\mathrm{EF}_{d}\right.$ 's, mean $\left.\pm \mathrm{SE}\right)$ from different treatments of the investigated rotations.

\begin{tabular}{|c|c|c|c|c|}
\hline & Period & Treatment & Fluxes $\left(\mathrm{kg} \mathrm{Nha}^{-1}\right)$ & $\mathrm{EF}_{d}(\%)$ \\
\hline \multirow[t]{6}{*}{ 2008-2009 rotation } & \multirow[t]{2}{*}{ Maize } & $\mathrm{CK}$ & $0.6 \pm 0.2$ & - \\
\hline & & NP & $7.2 \pm 1.2$ & $3.8 \pm 0.7$ \\
\hline & \multirow[t]{2}{*}{ Wheat } & CK & $0.9 \pm 0.001$ & - \\
\hline & & NP & $2.2 \pm 0.5$ & $0.80 \pm 0.31$ \\
\hline & \multirow[t]{2}{*}{ Annual } & $\mathrm{CK}$ & $1.5 \pm 0.2$ & - \\
\hline & & NP & $9.4 \pm 1.7$ & $2.4 \pm 0.5$ \\
\hline \multirow[t]{6}{*}{ 2009-2010 rotation } & \multirow[t]{2}{*}{ Maize } & $\mathrm{CK}$ & $0.9 \pm 0.02$ & - \\
\hline & & NP & $2.8 \pm 0.02$ & $1.1 \pm 0.02$ \\
\hline & \multirow[t]{2}{*}{ Wheat } & CK & $1.1 \pm 0.01$ & - \\
\hline & & NP & $1.3 \pm 0.03$ & $0.12 \pm 0.02$ \\
\hline & \multirow[t]{2}{*}{ Annual } & CK & $2.0 \pm 0.01$ & - \\
\hline & & NP & $4.0 \pm 0.03$ & $0.60 \pm 0.01$ \\
\hline \multirow[t]{6}{*}{ 2010-2011 rotation } & \multirow[t]{2}{*}{ Maize } & CK & $0.4 \pm 0.01$ & - \\
\hline & & NP & $3.0 \pm 0.1$ & $1.5 \pm 0.06$ \\
\hline & \multirow[t]{2}{*}{ Wheat } & CK & $0.8 \pm 0.03$ & - \\
\hline & & NP & $2.0 \pm 0.1$ & $0.73 \pm 0.06$ \\
\hline & \multirow[t]{2}{*}{ Annual } & CK & $1.3 \pm 0.02$ & - \\
\hline & & NP & $5.0 \pm 0.3$ & $1.1 \pm 0.09$ \\
\hline \multirow[t]{6}{*}{ 2011-2012 rotation } & \multirow[t]{2}{*}{ Maize } & CK & $0.5 \pm 0.3$ & - \\
\hline & & NP & $4.7 \pm 0.3$ & $2.4 \pm 0.2$ \\
\hline & \multirow[t]{2}{*}{ Wheat } & CK & $2.3 \pm 0.3$ & - \\
\hline & & NP & $7.8 \pm 0.4$ & $3.3 \pm 0.3$ \\
\hline & \multirow[t]{2}{*}{ Annual } & CK & $2.7 \pm 0.6$ & - \\
\hline & & NP & $12.5 \pm 0.1$ & $2.9 \pm 0.2$ \\
\hline
\end{tabular}

the changes of meteorological condition that affected the soil temperature and moisture. The annual cumulative $\mathrm{N}_{2} \mathrm{O}$ emissions from the $\mathrm{CK}$ treatment $\left(F_{1}, \mathrm{~kg} \mathrm{Nha}^{-1}\right)$ significantly correlated with the annual total rainfall intensities $\left(X_{1}, \mathrm{~mm}\right)$, and the relationship fitted the following equation:

$F_{1}=5.6 \times 10^{-10} X_{1}^{3.7}, N=4, R^{2}=0.75, P<0.05$.

It indicated that rainfall was a dominant factor for controlling $\mathrm{N}_{2} \mathrm{O}$ emission from the agricultural field without fertilization. As for the NP treatment, there was no evident correlation between the annual cumulative $\mathrm{N}_{2} \mathrm{O}$ emissions and rainfall intensities. Significant linear correlations were only observed between the fertilizer-induced $\mathrm{N}_{2} \mathrm{O}$ emissions $(F$, $\left.\mathrm{kg} \mathrm{Nha}^{-1}\right)$ during the periods of 10 days after fertilization and the amounts of rainfall $(X, \mathrm{~mm})$ from 4 days before to 10 days after fertilization in the maize, wheat seasons and whole year. The equations could be orderly expressed as

$F_{\text {maize }}=0.035 X_{\text {maize }}-0.48, \mathrm{~N}=4, R^{2}=0.93, P<0.05$,

$F_{\text {wheat }}=0.077 X_{\text {wheat }}-0.11, \mathrm{~N}=4, R^{2}=0.94, P<0.05$,

$F_{\text {year }}=0.048 X_{2}-1.1, \mathrm{~N}=4, R^{2}=0.99, P<0.05$.
Because the cumulative $\mathrm{N}_{2} \mathrm{O}$ emission from the NP treatment during the periods of 10 days after fertilization accounted for $\sim 50 \%$ of the total cumulative $\mathrm{N}_{2} \mathrm{O}$ emissions, the rainfall events far from fertilization events only made a modest contribution to the total cumulative $\mathrm{N}_{2} \mathrm{O}$ emissions. The rainfall events just before and after fertilization might favor fostering the community of microorganisms and promoting $\mathrm{N}_{2} \mathrm{O}$ formation. Therefore, it is easy to understand why the strong correlation only limited between the fertilizer-induced $\mathrm{N}_{2} \mathrm{O}$ emissions during the periods of 10 days after fertilizations and the amounts of rainfall around fertilization events.

There was no significant difference between the CK and NP treatments during the periods of 4 years excluding the 10-day durations following each fertilization event ( $T$ test, $P>0.05$ ), and the yearly management (fertilization rate and irrigation) of the agricultural field was almost the same in recent years. Therefore, only based on rainfall, the annual cumulative $\mathrm{N}_{2} \mathrm{O}$ emissions $\left(F_{\text {annual }}, \mathrm{kg} \mathrm{Nha}^{-1}\right.$ ) from the agriculture field could be obtained by integrating the Eqs. (2) and (5) as follows:

$F_{\text {annual }}=5.6 \times 10^{-10} X_{1}^{3.7}+0.048 X_{2}-1.1$.

It should be mentioned that the above estimation could be only applied to limit area where the rainfall is nearly identical and fertilization rate and irrigation practice are similar to this study. Because the cumulative $\mathrm{N}_{2} \mathrm{O}$ emissions usually 
Table 4. Summary of $\mathrm{N}_{2} \mathrm{O}$ emissions from maize-wheat soils in the NCP.

\begin{tabular}{|c|c|c|c|c|c|}
\hline Location & Year & $\begin{array}{l}\text { Total N } \\
\left(\mathrm{kg} \mathrm{Nha}^{-1} \mathrm{yr}^{-1}\right)\end{array}$ & $\begin{array}{l}\text { Cumulative } \\
\text { fluxes } \\
\left(\mathrm{kg} \mathrm{Nha}^{-1} \mathrm{yr}^{-1}\right)\end{array}$ & $\begin{array}{l}\mathrm{EF}_{d} \\
(\%)\end{array}$ & References \\
\hline \multirow{4}{*}{$\begin{array}{l}\text { Wangdu, } \\
\text { Hebei }\end{array}$} & 2008-2009 & 335 & 9.4 & 2.4 & This study \\
\hline & 2009-2010 & 333 & 4.0 & 0.60 & This study \\
\hline & 2010-2011 & 341 & 5.0 & 1.1 & This study \\
\hline & 2011-2012 & 341 & 12.5 & 2.9 & This study \\
\hline \multirow{5}{*}{$\begin{array}{l}\text { Quzhou, } \\
\text { Hebei }\end{array}$} & 2004-2005 & 135 & 5.0 & 1.0 & Wang et al. (2008) \\
\hline & & 270 & 6.0 & 0.87 & \\
\hline & 2005-2006 & 270 & 4.9 & 0.96 & Li et al. (2010) \\
\hline & 2009-2010 & 380 & 2.4 & 0.41 & Hu et al. (2013) \\
\hline & 2010-2011 & 380 & 1.9 & 0.37 & \\
\hline Luancheng, & 1992-1993 & 300 & 1.6 & 0.23 & Zeng et al. (1995) \\
\hline \multirow[t]{3}{*}{ Hebei } & 2007-2008 & 200 & 0.89 & 0.12 & Wang et al. (2009) \\
\hline & & 400 & 1.1 & 0.10 & \\
\hline & & 600 & 1.4 & 0.13 & \\
\hline Huantai, & 2008-2009 & 600 & 4.0 & 0.59 & Cui et al. (2012) \\
\hline \multirow{6}{*}{ Shandong } & 2008-2009 & 644 & 4.0 & 0.58 & Yan et al. (2013) \\
\hline & 2009-2010 & 464 & 2.5 & 0.48 & Shi et al. (2013) \\
\hline & 2011-2012 & 647 & 5.3 & 0.75 & \\
\hline & & 467 & 4.8 & 0.96 & \\
\hline & & 600 & 2.2 & 0.21 & \\
\hline & & 218 & 1.8 & 0.37 & \\
\hline Yucheng, & 1995-1996 & 420 & 2.9 & 0.67 & Dong et al. (2000) \\
\hline Shandong & 2004-2005 & 312 & 4.4 & - & Sun et al. (2008) \\
\hline Fengqiu, & 2002-2003 & 300 & 0.77 & 0.21 & Meng et al. (2005) \\
\hline \multirow[t]{6}{*}{ Henan } & 2004-2005 & 300 & 2.5 & 0.61 & Ding et al. (2007) \\
\hline & & 500 & 4.5 & 0.77 & \\
\hline & 2004-2005 & 300 & 2.4 & 0.63 & Cai et al. (2013) \\
\hline & 2005-2006 & 300 & 3.0 & 0.95 & \\
\hline & 2006-2007 & 300 & 2.9 & 0.88 & \\
\hline & 2008-2009 & 300 & 1.4 & 0.39 & Ding et al. (2013) \\
\hline
\end{tabular}

linearly correlate with fertilization rates (Henault et al., 1998; De Klein et al., 2006; Halvorson et al., 2008), the above experiential algorithm for estimating the annual cumulative $\mathrm{N}_{2} \mathrm{O}$ emissions from agricultural fields could be expressed in a more general form:

$F_{\text {annual }}=A X_{1}^{n}+F / B X_{2}+C$,

where $n, A, B$ and $C$ are empirical constants, which can be estimated with field measurements, and $F$ is the annual application rate of $\mathrm{N}$-fertilizer. The empirical equation in this study was similar to that established by Lu et al. (2006), who investigated the $\mathrm{N}_{2} \mathrm{O}$ emissions from upland soil between 1982 and 2003 in the literature, and also deduced a model including background and fertilizer-induced $\mathrm{N}_{2} \mathrm{O}$ emissions based on annual precipitation and fertilizer $\mathrm{N}$ input. Nevertheless, unlike our result, Lu et al. (2006) reported a linear regression expression between participation and background $\mathrm{N}_{2} \mathrm{O}$ emission. To verify the applicability of the above algorithm, more field studies in various agricultural fields are needed. If the applicability of the above algorithm were widely verified, the regional, or even global, annual cumulative $\mathrm{N}_{2} \mathrm{O}$ emissions from agricultural fields could be easily estimated just based on fertilization rates and rainfall in different regions.

\subsection{Comparison with previous studies}

The results of studies about maize-wheat rotation field in the NCP are shown in Table 4. It is evident that there are very large temporal-spatial variations of the cumulative $\mathrm{N}_{2} \mathrm{O}$ emissions and $\mathrm{EF}_{d}$ reported in the NCP. With only the exception of the data in the 2009-2011 maize-wheat rotations, the cumulative $\mathrm{N}_{2} \mathrm{O}$ emissions from the NP treatment in this study were $33-108 \%$ greater than the upper limit value reported in the literature. The $\mathrm{EF}_{d}$ value of $0.60 \%$ in 20092010 was in good agreement with the values reported by Dong et al. (2000), Ding et al. (2007), Cui et al. (2012), Cai et al. (2013) and Yan et al. (2013), and of $1.1 \%$ in 20102011 was in line with the values reported by $\mathrm{Li}$ et al. (2010), Wang et al. (2008), Cai et al. (2013) and Yan et al. (2013). 

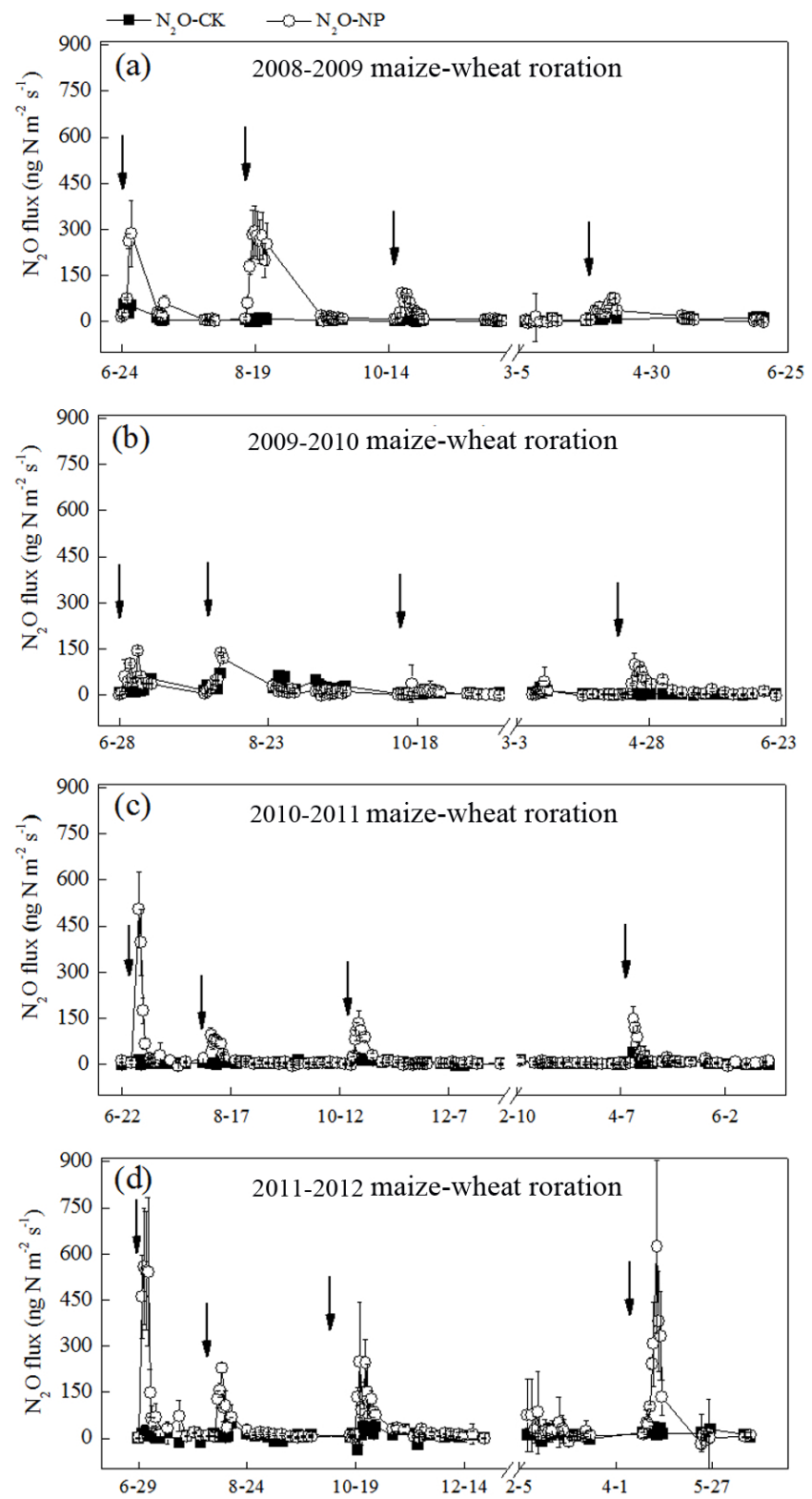

Fig. 2. $\mathrm{N}_{2} \mathrm{O}$ emissions from the $\mathrm{CK}$ and $\mathrm{NP}$ treatments during the $\mathrm{N}_{2} \mathrm{O}$ measurement periods in the 2008-2009 (a), 2009-2010 (b), 2010-2011 (c) and 2011-2012 (d) maize-wheat rotations. Arrows show fertilizer applications.

The $\mathrm{EF}_{d}$ 's from the NP treatment in 2008-2009 and 20112012 were two times greater than the upper limit value reported in the NCP, but were still within the uncertainty range recommended by the IPCC (0.3-3\%; De Klein et al., 2006). In comparison with 2009-2010 and 2010-2011, as shown in Figs. 1 and 2, the higher $\mathrm{N}_{2} \mathrm{O}$ emissions in 2008-2009 and 2011-2012 were mainly ascribed to the rain events with relatively high frequency or great intensity just around fertilization events. In addition, the relatively high sampling frequency conducted in this study may be partially responsible for the higher $\mathrm{EF}_{d}$ 's. Smith and Dobbie (2001) investigated the impact of sampling frequency on cumulative $\mathrm{N}_{2} \mathrm{O}$ fluxes by manual chambers with sampling intervals of 3-7 days and auto-chambers with sampling intervals of 8 hours, and found that the short-lived $\mathrm{N}_{2} \mathrm{O}$ peaks after fertilization can not be detected by manual sampling under low sampling frequency. The sampling frequency in this study was each day with a duration at least 10 days after each fertilization event, whereas the sampling frequencies for most previous studies in the NCP were 1-2 times weekly. On the other hand, the very good linear $\left(R^{2}=0.9996\right)$ response to $\mathrm{N}_{2} \mathrm{O}$ concentration $(0.093-1.97 \mathrm{ppm})$ of the GC-ECD improved by our group could make sure the accurate quantification of $\mathrm{N}_{2} \mathrm{O}$ in the air samples with remarkably different $\mathrm{N}_{2} \mathrm{O}$ concentrations. Most of commercial instruments of GC-ECD have been found to be a non-linear response to $\mathrm{N}_{2} \mathrm{O}$ concentrations (Hall et al., 2007; Zheng et al., 2008; Fang et al., 2010; Wang et al., 2010), and thus the single-point calibration for $\mathrm{N}_{2} \mathrm{O}$ flux measurement predominately used by previous studies would probably result in relatively low $\mathrm{EF}_{d}$ 's.

To check the possible influence of the soils from different areas in the NCP on $\mathrm{N}_{2} \mathrm{O}$ emission, soil samples were collected from four sampling sites (Fengqiu, Luancheng, Yucheng and Beijing) where $\mathrm{N}_{2} \mathrm{O}$ emissions have been investigated. $\mathrm{N}_{2} \mathrm{O}$ emissions from the four fields were simultaneously measured under the same fertilization and irrigation management at the agricultural field of this study (data not shown), and no remarkable difference of $\mathrm{N}_{2} \mathrm{O}$ emissions from the four agricultural soils was found in comparison with the uncertainty of the triplet replicates for the agricultural soil investigated in this study. Therefore, the very large temporalspatial variations of the cumulative $\mathrm{N}_{2} \mathrm{O}$ emissions and $\mathrm{EF}_{d}$ 's from the agricultural fields in the NCP might also be partially ascribed to the different weather conditions (especially rainfall as mentioned above) in different areas and years during the investigations. To some extent, the field simulation experiment confirmed that the results investigated at any agricultural fields in the NCP could be applied for estimating the annual cumulative $\mathrm{N}_{2} \mathrm{O}$ emission and the fertilizer-induced $\mathrm{N}_{2} \mathrm{O}$ emission from the agricultural field in the NCP. The estimation would be more representative based on the average value of many years' investigations, because the multi-year rainfall in one small region might partially reflect the uneven distribution of rainfall in different areas of the NCP.

\section{Conclusions}

Large interannual variations of $\mathrm{N}_{2} \mathrm{O}$ emissions were observed from the maize-wheat field in the NCP during the 4 successive years. Precipitation was primarily responsible for the interannual variation of $\mathrm{N}_{2} \mathrm{O}$ emission. The significant correlation between cumulative $\mathrm{N}_{2} \mathrm{O}$ emission and precipitation obtained in this study may provide an approach to 
estimate $\mathrm{N}_{2} \mathrm{O}$ emission from the area where the rainfall and fertilization rate are similar to this study.

Acknowledgements. This study was funded by the National Science and Technology Pillar Program (no. 2013BAD11B03), the Strategic Priority Research Program of the Chinese Academy of Sciences (no. XDB05010100), the Chinese National Natural Science Foundation (no. 41075094 and 21177140), and the National Basic Research and the Development Program 973 (no. 2010CB732304).

Edited by: X. Wang

\section{References}

Barton, L., Kiese, R., Gatter, D., Butterbach-Bahl, K., Buck, R., Hinz, C., and Murphy, D. V.: Nitrous oxide emissions from a cropped soil in a semi-arid climate, Glob. Change Biol., 14, 177192, 2008.

Bolle, H. J., Seiler, W., and Bolin, B.: Other greenhouse gases and aerosols, in: The Greenhouse Effect, Climate Change and Ecosystems, SCOPE 29 edited by: Bolin, B., Döös, B. R., Jäger, J., and Warrick, R. A., Wiley, New York, 157-203, 1986.

Bouwman, A. F.: Direct emission of nitrous oxide from agricultural soils, Nutr. Cycl. Agroecosys., 46, 53-70, 1996.

Bouwman, A. F., Boumans, L. J. M., and Batjes, N. H.: Emissions of $\mathrm{N}_{2} \mathrm{O}$ and $\mathrm{NO}$ from fertilized fields: summary of available measurement data, Global Biogeochem. Cy., 16, 1-13, 2002.

Cai, Y. J., Ding, W. X., and Luo, J. F.: Nitrous oxide emissions from Chinese maize-wheat rotation systems: a 3-year field measurement, Atmos. Environ., 65, 112-122, 2013.

Chapuis-Lardy, L., Wrage, N., Metay, A., Chotte, J. L., and Bernoux, M.: Soils, a sink for $\mathrm{N}_{2} \mathrm{O}$, A review, Glob. Change Biol., 13, 1-17, 2007.

Chen, S., Huang, Y., and Zou, J.: Relationship between nitrous oxide emission and winter wheat production, Biol. Fertil. Soils, 44, 985-989, 2008.

Crutzen, P. J.: The influence of nitrogen oxides on the atmospheric ozone content, Q. J. Roy. Meteorl. Soc., 96, 320-325, , 1970.

Cui, F., Yan, G. X., Zhou, Z. X., Zheng, X. H., and Deng, J.: Annual emissions of nitrous oxide and nitric oxide from a wheat-maize cropping system on a silt loam calcareous soil in the North China Plain, Soil Biol. Biochem., 48, 10-19, 2012.

De Klein, C., Novoa, R. S. A., Ogle, S., Smith, K. A., Rochette, P., Wirth, T. C., McConkey, B. G., Mosier, A., and Rypdal, K.: $\mathrm{N}_{2} \mathrm{O}$ Emissions from managed soils, and $\mathrm{CO}_{2}$ emissions from Lime and Urea Application, in: 2006 IPCC Guidelines for National Greenhouse Gas Inventories, Vol 4-Agriculture, Forestry and Other Land Use, edited by: Eggleston, S., Buendia, L., Miwa, K., Ngara, T., and Tanabe, K., Institute for Global Environmental Strategies, Japan, 11.1-11.54, 2006.

Ding, W., Luo, J., Li, J., Yu, H., Fan, J., and Liu, D.: Effect of longterm compost and inorganic fertilizer application on background $\mathrm{N}_{2} \mathrm{O}$ and fertilizer-induced $\mathrm{N}_{2} \mathrm{O}$ emissions from an intensively cultivated soil, Sci. Total Environ., 465, 115-124, 2013.

Ding, W. X., Cai, Y., Cai, Z. C., Yagi, K., and Zheng, X. H.: Nitrous oxide emissions from an intensively cultivated maize-wheat ro- tation soil in the North China Plain, Sci. Total Environ., 373, 501-511, 2007.

Dobbie, K. E. and Smith, K. A.: The effects of temperature, waterfilled pore space and land use on $\mathrm{N}_{2} \mathrm{O}$ emissions from an imperfectly drained gleysol, Eur. J. Soil Sci., 52, 667-673, 2001.

Dong, Y. S., Dieter, S., Manfred, D., Qi, Y. C., and Zhang, S.: $\mathrm{N}_{2} \mathrm{O}$ emissions from agricultural soils in the North China Plain: the effect of chemical nitrogen fertilizer and organic manure, J. Environ. Sci., 12, 463-468, 2000.

Fang, S. X., Zhou, L. X., Zhang, F., Yao, B., Zhang, X. C., Zang, K. P., Xu, L., Liu, L. X., Wen, M., and Gu, S.: Dual channel GC system for measuring background atmospheric $\mathrm{CH}_{4}, \mathrm{CO}, \mathrm{N}_{2} \mathrm{O}$ and $\mathrm{SF}_{6}$, Acta Scientiae Circumstantiae, 30, 52-59, 2010 (in Chinese).

Firestone, M. K. and Davidson, E. A.: Microbiological basis of $\mathrm{NO}$ and $\mathrm{N}_{2} \mathrm{O}$ production and consumption in soil, in: Exchange of Trace Gases between Terrestrial Ecosystems and the Atmosphere, edited by: Andreae, M. O. and Schimel, D. S., Wiley, Chichester, 7-21, 1989.

Hall, B. D., Dutton, G. S., and Elkins, J. W.: The NOAA nitrous oxide standard scale for atmospheric observations, J. Geophys. Res., 112, D09305, doi:200710.1029/2006JD007954, 2007.

Halvorson, A. D., Del Grosso, S. J., and Reule, C. A.: Nitrogen, tillage, and crop rotation effects on nitrous oxide emissions from irrigated cropping systems, J. Environ. Qual., 37, 1337-1344, 2008.

Hao, X., Chang, C., Carefoot, J. M., Janzen, H. H., and Ellert, B. H.: Nitrous oxide emissions from an irrigated soil as affected by fertilizer and straw management, Nutr. Cycl. Agroecosys., 60, $1-8,2001$.

Henault, C., Devis, X., Page, S., Justes, E., Reau, R., and Germon, J. C.: Nitrous oxide emissions under different soil and land management conditions, Biol. Fert. Soils, 26, 199-207, 1998.

Hu, X. K., Su, F., Ju, X. T., Gao, B., Oenema, O., Christie, P., Huang, B. X., Jiang, R. F., and Zhang, F. S.: Greenhouse gas emissions from a wheat-maize double cropping system with different nitrogen fertilization regimes, Environ. Pollut., 176, 198207, 2013.

Huang, Y., Zou, J., Zheng, X., Wang, Y., and Xu, X.: Nitrous oxide emissions as influenced by amendment of plant residues with different C:N ratios, Soil Biol. Biochem., 36, 973-981, 2004.

Khalil, M. I., Schmidhalter, U., and Gutser, $\mathrm{R}_{\text {.: }} \mathrm{N}_{2} \mathrm{O}, \mathrm{NH}_{3}$ and $\mathrm{NO}_{X}$ emissions as a function of urea granule size and soil type under aerobic conditions, Water Air Soil Poll., 175, 127-148, 2006.

Li, H., Qiu, J., Wang, L., Tang, H., Li, C., and Van Ranst, E.: Modelling impacts of alternative farming management practices on greenhouse gas emissions from a winter wheat-maize rotation system in China, Agr. Ecosyst. Environ., 135, 24-33, 2010.

Liu, C. M., Yu, J. J., and Kendy, E.: Groundwater exploitation and its impact on the environment in the North China Plain, Water Int., 26, 265-272, 2001.

Liu, X. H. and Mu, Z. G. (Eds.): Cropping Systems in China, Agricultural Press of China, Beijing, 1993 (in Chinese).

Lu, Y., Huang, Y., Zou, J., and Zheng, X.: An inventory of $\mathrm{N}_{2} \mathrm{O}$ emissions from agriculture in China using precipitation-rectified emission factor and background emission, Chemosphere, 65, 1915-1924, 2006. 
Mahmood, T., Ali, R., Malik, K. A., and Shamsi, S. R. A.: Nitrous oxide emissions from an irrigated sandy-clay loam cropped to maize and wheat, Biol. Fertil. Soils, 27, 189-196, 1998.

Meixner, F. X. and Yang, W. X.: Biogenic emissions of nitric oxide and nitrous oxide from arid and semi-arid land, in: Dryland Ecohydrology, edited by D'Odorico, P. and Porporato, A., Springer, Dordrecht, 233-255, 2006.

Meng, L., Ding, W. X., and Cai, Z. C.: Long-term application of organic manure and nitrogen fertilizer on $\mathrm{N}_{2} \mathrm{O}$ emissions, soil quality and crop production in a sandy loam soil, Soil Biol. Biochem., 37, 2037-2045, 2005.

Raich, J. W. and Tufekcioglu, A.: Vegetation and soil respiration: correlations and controls, Biogeochemistry, 48, 71-90, 2000.

Rowlings, D. W., Grace, P. R., Kiese, R., and Weier, K. L.: Environmental factors controlling temporal and spatial variability in the soil-atmosphere exchange of $\mathrm{CO}_{2}, \mathrm{CH}_{4}$ and $\mathrm{N}_{2} \mathrm{O}$ from an Australian subtropical rainforest, Glob. Change Biol., 18, 726-738, 2012.

Ruser, R., Flessa, H., Russow, R., Schmidt, C., Buegger, F., and Munch, J. C.: Emission of $\mathrm{N}_{2} \mathrm{O}, \mathrm{N}_{2}$, and $\mathrm{CO}_{2}$ from soil fertilized with nitrate: effect of compaction, soil moisture and rewetting, Soil Biol. Biochem., 38, 263-274, 2006.

Scheer, C., Wassmann, R., Klenzler, K., Lbragimov, N., and Eschanov, R.: Nitrous oxide emissions from fertilized irrigated cotton (Gossypium hirsutum L.) in the Aral Sea Basin, Uzbekistan: influence of nitrogen applications and irrigation practices, Soil Biol. Biochem., 40, 290-301, 2008.

Shi, Y., Wu, W., Meng, F., Zhang, Z., Zheng, L., and Wang, D.: Integrated management practices significantly affect $\mathrm{N}_{2} \mathrm{O}$ emissions and wheat-maize production at field scale in the North China Plain, Nutr. Cycl. Agroecosystems, 95, 203-218, 2013.

Smith, K. A.: The potential for feedback effects induced by global warming on emissions of nitrous oxide by soils, Glob. Change Biol., 3, 327-338, 1997.

Smith, K. A. and Dobbie, K. E.: The impact of sampling frequency and sampling times on chamber-based measurements of $\mathrm{N}_{2} \mathrm{O}$ emissions from fertilized soils, Glob. Change Biol., 7, 933-945, 2001.

Smith, K. A., Ball, T., Conen, F., Dobbie, K. E., Massheder, J., and Rey, A.: Exchange of greenhouse gases between soil and atmosphere: interactions of soil physical factors and biological processes, Eur. J. Soil Sci., 54, 779-791, 2003.

Sun, Y. L., Lu, P. L., Li, J., Yu, Q., Sun, S. B., Wang, J. S., and Ouyang, Z.: Characteristics of soil $\mathrm{N}_{2} \mathrm{O}$ flux in a winter wheatsummer maize rotation system in North China Plain and analysis of influencing factors, Chinese J. Agrometeorol., 29, 1-5, 2008 (in Chinese).

Wang, L. G., Li, H., and Qiu, J. J.: Characterization of Emissions of Nitrous Oxide from Soils of Typical Crop Fields in Huang-HuaiHai Plain, Scientia Agricultura Sinica, 41, 1248-1254, 2008 (in Chinese).
Wang, Y., Xue, M., Zheng, X., Ji, B., Du, R., and Wang, Y.: Effects of environmental factors on $\mathrm{N}_{2} \mathrm{O}$ emission from and $\mathrm{CH}_{4}$ uptake by the typical grasslands in the Inner Mongolia, Chemosphere, 58, 205-215, 2005.

Wang, Y., Wang, Y., and Ling, H.: A new carrier gas type for accurate measurement of $\mathrm{N}_{2} \mathrm{O}$ by GC-ECD, Adv. Atmospheric Sci., 27, 1322-1330, 2010.

Wang, Y. Y., Hu, C. S., Cheng, Y. S., Zhang, Y. M., Ming, H., and Yang, P. P.: Carbon sequestrations and gas regulations in summer-maize and winter-wheat rotation ecosystem affected by nitrogen fertilization in the piedmont plain of Taihang Mountains, China, J. Agro-Environ. Sci., 28, 1508-1515, 2009 (in Chinese).

Yamulki, S., Goulding, K. W. T., Webster, C. P., and Harrison, R. M.: Studies on $\mathrm{NO}$ and $\mathrm{N}_{2} \mathrm{O}$ fluxes from a wheat field, Atmos. Environ., 29, 1627-1635, 1995.

Yan, G., Zheng, X., Cui, F., Yao, Z., Zhou, Z., Deng, J., and Xu, Y.: Two-year simultaneous records of $\mathrm{N}_{2} \mathrm{O}$ and $\mathrm{NO}$ fluxes from a farmed cropland in the northern China plain with a reduced nitrogen addition rate by one-third, Agric. Ecosyst. Environ., 178, 39-50, 2013.

Zeng, J. H., Wang, Z. P., Zhang, Y. M., Song, W. Z., Wang, S. B., and $\mathrm{Su}, \mathrm{W}$. H.: Flux of $\mathrm{N}_{2} \mathrm{O}$ emission from the fields in a wheat and maize rotation system, Chinese J. Environ. Sci., 16, 32-35, 1995 (in Chinese).

Zhang, Y. M., Chen, D. L., Zhang, J. B., Edis, R., Hu, C. S., and Zhu, A. N.: Ammonia volatilization and denitrification losses from an irrigated maize-wheat rotation field in the North China Plain, Pedosphere, 14, 533-540, 2004.

Zhang, Y. Y., Liu, J. F., Mu, Y. J., Pei, S. W., Lun, X. X., and Chai, F. H.: Emissions of nitrous oxide, nitrogen oxides and ammonia from a maize field in the North China Plain, Atmos. Environ., 45, 2956-2961, 2011.

Zhang, Y. Y., Liu, J. F., Mu, Y. J., Xu, Z., Pei, S. W., Lun, X. X., and Zhang, Y.: Nitrous oxide emissions from a maize field during two consecutive growing seasons in the North China Plain, J. Environ. Sci., 24, 1-9, 2012.

Zhang, Y. Y., Mu, Y. J., Fang, S. X., and Liu, J. F.: An improved GC-ECD method for measuring atmospheric $\mathrm{N}_{2} \mathrm{O}$, J. Environ. Sci., 25, 547-553, 2013.

Zheng, X., Mei, B., Wang, Y., Xie, B., Wang, Y., Dong, H., Xu, H., Chen, G., Cai, Z., Yue, J., Gu, J., Su, F., Zou, J., and Zhu, J.: Quantification of $\mathrm{N}_{2} \mathrm{O}$ fluxes from soil-plant systems may be biased by the applied gas chromatograph methodology, Plant Soil, 311, 211-234, 2008. 